\title{
Effect Of Physical Exercise On Fatigue In Cervical Cancer Patients
}

\author{
Fatwa Imelda ${ }^{1}$, Nur Afi Darti², Farida Linda Sari Siregar ${ }^{3}$ \\ 1,2,3 Lecture in Faculty Of Nursing Universitas Sumatera \\ Utara Email: heristinadewi18@gmail.com
}

\begin{abstract}
Abstrak
Kanker serviks adalah masalah kesehatan pertama bagi wanita di Indonesia dengan tingkat kematian yang tinggi. Lebih dari $80 \%$ pasien dengan kanker serviks mengalami kelelahan sebelum dan setelah kemoterapi. Kelelahan adalah masalah umum pada pasien dengan kanker serviks, kelelahan karena kanker berbeda dari kelelahan orang normal. Kelelahan menyebabkan keterbatasan: fisik, perawatan, ketergantungan pada petugas kesehatan, berdampak pada kualitas hidup pasien, dan bahkan meningkatkan morbiditas. Salah satu pemberdayaan diri yang direkomendasikan untuk mengelola kelelahan paska terapi adalah latihan fisik. untuk menguji pengaruh latihan fisik terhadap kelelahan pada pasien kanker serviks. Penelitian eksperimental kuasi dengan pretest posttest dengan desain kelompok kontrol yang digunakan. Tiga puluh empat responden dipilih menggunakan purposive sampling dalam penelitian ini, dimana 17 responden secara acak ditugaskan dalam kelompok eksperimen dan kontrol. Skala Kelelahan Piper (PFS) digunakan untuk mengukur tingkat kelelahan. Paired t-test dan Independent $t$-test digunakan untuk analisis data.Ada pengaruh yang signifikan dari latihan fisik pada penurunan tingkat kelelahan pada pasien kanker serviks dengan p-value 0,000 $(p<0,05), t=15,981$ pada kelompok eksperimen tetapi pada kelompok kontrol, tidak ada efek latihan fisik yang signifikan pada penurunan tingkat kelelahan pada pasien kanker serviks dengan nilai-p 0,142 ( $p>0,05), t=-2,732$. Perbedaan yang signifikan antara posttest dalam eksperimen dan kelompok kontrol dengan $p$-value $0,000(p<0,05), t=-5,7794$. Latihan fisik dapat direkomendasikan dalam mengurangi tingkat kelelahan pada pasien dengan kanker serviks yang dapat meningkatkan kualitas hidup pasien dengan kanker serviks.
\end{abstract}

Kata Kunci: Kanker Servik, Latihan Fisk, Kelelahan

\section{Abstract}

Cervical cancer is the first health problem for women in Indonesia with a high mortality rate. More than $80 \%$ of patients with cervical cancer experience fatigue before during and after chemotherapy. Fatigue is a common problem in patients with cervical cancer, fatigue due to cancer is different from the fatigue of normal people. Fatigue cause limitations: physical, treatment, dependence on health workers, have an impact on the quality of life of patients, and even increasing morbidity. One of the self-empowerment recommended for managing posttherapy fatigue is physical exercise. Objectives: To examine the effect of physical exercise on fatigue in cervical cancer patients. A quasi-experimental research with pretest posttest with control group design was used. Thirty-four respondents were selected using purposive sampling in this study, which 17 respondents were randomly assigned in the experiment and control group. The Piper Fatigue Scale (PFS) was used to measure fatigue level. Paired t-test and independent $t$-test were used for data analysis. There was a significant effect of physical exercise on the decrease of fatigue levels in cervical cancer patients with $p$-value $0.000(p<0.05), t=$ 
15.981 in experimental group but in control group, there was not a significant effect of physical exercise on the decrease of fatigue levels in cervical cancer patients with $p$-value 0.142 ( $p>0.05)$, $t=-2.732$. A significant difference between posttest in the experiment and control group with $p$ value 0.000 ( $p<0.05), t=-5.7794$. physicalexercise can be recommended in reducing fatigue levels in patients with cervical cancer that can be the increasing quality of life patients with cervical cancer.

\section{Keywords: Cervical cancer, Physical exercise, Fatigue}

Info Artikel :

Artikeldikirimpada 18 Desember 2018

Artikeldirevisipada22Februari 2019

Artikelditerimapada06 Maret 2019

DOI: http://dx.doi.org/10.21927/jnki.2019.7(1).41-46

\section{INTRODUCTION}

Cervical cancer is characterized by abnormal cells in the cervix that are almost 90 percent caused by Human Papillomavirus (HPV). Several factors suspected to be risk factors for cervical precancerous lesions include socioeconomic status, age at first sexual intercourse, number of partners, multiparity, smoking and history of venereal disease(1). With a better diagnosis of cancer, it will increase the number of new cases of cancer(2). The prevalence of cancer in Indonesia is based on the cancer Sub-directorate (Subdit) of the Directorate of Non-Communicable. Disease Control (NCDC) of the Ministry of Health of the Republic of Indonesia as of January 20, 2014 of a total of $36,761,000$ women aged $30-50$ years, the prevalence of cervical cancer is 1.3 per 1000 people or about 850 people(3).

More than $80 \%$ of cancer sufferers experience fatigue(4). Every cancer patient will get one or more types of therapy such as chemotherapy, surgery, radiation, and others. Cancer sufferers experience cancer fatigue: before, during and after chemotherapy(5). Nearly $30-99 \%$ of cancer sufferers experience severe stage fatigue(6).

Fatigue is a subjective perception of symptoms that are felt by cancer patients and is a complex/multidimensional syndrome(7). Fatigue is often expressed as a sensation of the body feeling tired, easy to get tired, not feeling fresh/ insufficient to contain and lack of energy; while the mental aspect is perceived as a decrease: the ability to concentrate, plan and do work(8).
The main key to empowerment is knowledge, behavioral skills, and personal responsibilities. For this reason, an increase in partnerships between patients and health workers is needed. One of the self-empowerment recommended managing post-therapy fatigue is physical exercise. The physical self-management rehabilitation program shows a positive effect on fatigue and muscle function and rolefunction(9).

Physical activity is carried out by increasing strength, energy and fitness through regular exercise. The results of an individualized exercise study that can reduce fatigue due to cervical cancer, exercise is individualistic according to the ability of cancer patients also to prevent the spread of cancer therapy toxicity. This study aimed to determine the effect of physical exercise on fatigue levels in patients with cervical cancer scientifically.

\section{MATERIALS AND METHODS}

This study was quasi-experimental study with pretest-posttest control group design. This study was conducted from October 2017 to July 2018. Thirty-four respondent with cervical cancer who volunteered to participate in this study were selected using purposive. Inclusion criteria included: 1) patients with cervical cancer, 2) stage1-III B, 3) patients who experience fatigue, 4) able to be invited to communicate, 5) willing to be a respondent, 6) outpatients, and 7) do not have complications.

Physical exercise intervention is carried out for 21 days with 30 minutes each physical exercise, the physical exercise model that is 
carried out is by joining progressive muscle exercises and minimal physical exercise in bed.

The fatigue scale was used as a Piper Fatigue Scale (PFS) to measure the level of fatigue. The Piper Fatigue Scale consists of 22 questions with a numerical scale starting from 0 to 10 with an interpretation of $0=$ not fatigue, $1-3$ $=$ mild fatigue, $4-6=$ moderate fatigue, $7-10=$ severe fatigue.

Before the bivariate analysis, the normality test of the data was carried out first using the analytical method, the Shapiro-Wilk test. Data that is normally distributed will use statistical tests $t$ paired samples and Independent t-test. This statistical test was declared meaningful if the value of $p<0.05$ at the $95 \%$ confidence level.

\section{RESULTS AND DISCUSSION}

\section{Result}

Table 1. Fatigue level in the experiment and control group $(n=34)$

\begin{tabular}{lccccccccc}
\hline \multirow{2}{*}{ Fatigue level } & \multicolumn{4}{c}{ Experimental } & \multicolumn{3}{c}{ Control } \\
\cline { 2 - 10 } & \multicolumn{3}{c}{ Pre } & \multicolumn{2}{c}{ Post } & \multicolumn{2}{c}{ Pre } & \multicolumn{3}{c}{ Post } \\
\cline { 2 - 10 } & $\mathbf{F}$ & $\%$ & F & $\%$ & f & $\%$ & F & $\%$ \\
\hline $1-3$ (mild) & 4 & 23.5 & 15 & 88.1 & & 4 & 23.5 & 4 & 23.5 \\
4-6 (moderate) & 10 & 58.8 & 2 & 11.8 & 10 & 58.8 & 10 & 58.8 \\
7-10 (severe) & 3 & 17.6 & 0 & 0 & 3 & 17.6 & 3 & 17.6 \\
$\quad$ Total & 17 & 100 & 17 & 100 & 17 & 100 & 17 & 100
\end{tabular}

Table1 shows that the fatigue the intervention group on pretest data that experienced mild fatigue as many as 4 patients $(23.5 \%)$, moderate were 10 patients $(58.8 \%)$ and severe fatigue were 3 patients $(17.6 \%)$. Whereas in the posttest the level of fatigue in the intervention group experienced mild fatigue as many as 15 patients $(88.2 \%)$, moderate fatigue as 2 patients $(11.8 \%)$, severe fatigue as much $(0 \%)$. In control group, all respondents did not have a change in fatigue.

Table 2. Effect of physical exercise on fatigue level $(n=34)$

\begin{tabular}{lccc}
\hline \multicolumn{1}{c}{ Fatigue level } & Mean $\pm S D$ & t & $\boldsymbol{p}$-value \\
\hline Experiment group & & & \\
Pretest & $99.82 \pm 34.870$ & 15.9810 .000 \\
Posttest & $38.94 \pm 22.700$ & \\
\hline Control group & & \\
Pretest & $100.18 \pm 41.116$ & -2.7320 .142 \\
Posttest & $103.18 \pm 39.672$ & \\
\hline
\end{tabular}

Paired t-test results in the table 2 shows $p$ value $0.000(<0.05)$ in the experiment group. Which indicated that there was a significant effect of physical exercise on handling fatigue level in patients with cervical cancer. Meanwhile in the control group obtained $p$-value $0.142(p>0.05)$, indicated that there was no significant effect of physical exercise on handling fatigue level in patients with cervical cancer.

Table 3. Analysis of the difference in fatigue levels between the experiment and control group $(n=34)$

\begin{tabular}{lcccc}
\hline & Number (n) & Fatigue level Mean \pm SD & $\mathbf{t}$ & $\boldsymbol{p}$-value \\
Posttest & 17 & $38.94 \pm 22.700$ & -5.794 & 0.000 \\
Experiment & 17 & $103.18 \pm 39.672$ & & \\
Control & 17 & & & \\
\hline
\end{tabular}

A significant difference between posttest in the experiment and control group can be seen in table 3. The mean value for the control group was 103.18. While the mean value for the intervention group was 38.94. Based on the statistical tests that have been carried out obtained $t$ value of 5.7794 and $p$-value of $0.000(<0.05)$. This shows that there was a difference in the mean value of fatigue between the experimental and control group.

\section{Discussion}

The results showed that the level of fatigue pre and post-intervention did not experience a change in category, namely the majority of respondents still experienced moderate fatigue as many as 10 patients (58.8\%). There was a slight increase in the average fatigue level which meant that the control group remained in the category of moderate and severe fatigue. Because the control group did not do physical exercise and based on statistical tests obtained p-value $0.142(<0.05)$ which indicated that there was no a significant difference between the mean value of fatigue pre and post in the control group. The results of this study are in line with the study conducted by Wahyuni, Sudiana and Mariyanti who examined the walking exercise program at IbnuSina Hospital in Gresik with exercise intensity of 3-5 days per week in 3 weeks for 20 minutes which resulted in a p-value of $0.715(<0.05)$ which means there were no meaningful changes(10). 
This is also following a study by Vitkauskaitë, Juozaitytë, Druktenienë, and Bunevièius patients with cervical cancer will experience physical symptoms that are felt include feeling tired, tired, feeling insufficient, shortness of breath. Fatigue can be characterized by general energy deficiency, cognitive impairment, somnolence and mood disorders or muscle weakness. This problem can arise due to cancer itself and the effects of cancer therapy that is not lost with rest or additional sleep and can be caused by many factors such as anemia, sleep disturbances, pain, and emotional disturbances(11).

The results of research conducted on cervical cancer patients in the intervention group showed that the pre and post-intervention fatigue level in the intervention group experienced a change in category, namely from moderate fatigue to mild fatigue and obtained results from the study by analyzing data using paired t-test that in the intervention group decreased 60.8 points. There is a decrease in the average value of fatigue which means there is a decrease in the categorical level of moderate fatigue to mild fatigue because the intervention group performs physical exercise and based on statistical tests obtained $p$-value 0.000 $(<0.05)$ which indicated that there was a significant difference between values mean fatigue pre and post in the intervention group. The results of this study are in line with the study conducted by Cahyanti with p-value $0.001 \quad(<0.05)(12)$. The result of a study by Taukhid is also in line with the results of research conducted by researchers which showed differences and decreased levels of fatigue of cervical cancer patients before and after doing physical exercise with $\mathrm{p}=0.002$ $(<0.05)(13)$.

Based on the stage of patients with cervical cancer patients that the study in intervention patients the majority of patients were at stage 3 (50\%) which, following the statement of YoungMccaughan and Arzola(14). In his research, stage 3 and 4 cancer patients could still carry out homebased walking exercise. According to Labourey that daily physical activity can prevent and reduce the fatigue of patients for cancer patients undergoing chemotherapy(15).

The study by Sulistini found that patients with a higher level of education had good awareness to have a health check(16). Highly educated people can manage fatigue experienced(17). Therefore, in managing the level of fatigue it is necessary to pay attention to the level of education and the ability of patients to receive information.

The effect of physical exercise on fatigue in this study was identified by comparing the final value of fatigue symptoms between the intervention and control group using independent t-test statistical analysis. Based on the results of research conducted physical exercise performed on patients for two weeks 3 times a week for 30 minutes showed that based on the results of statistical tests using the t-dependent test obtained $p$-value $0.000(0.05)$. This means that there was a significant effect between the mean fatigue level in the intervention and control group before and after physical exercise so that it can be concluded that physical exercise can reduce the level of fatigue in cervical cancer patients.

The result of this study is in line with the study Dieli found that physical exercise carried out with 3 times a week with a duration of 30 minutes per day in cancer patients found a decrease in fatigue level, the results of the study with $p$-value 0.002 $(<0.05)$ shows the influence of physical exercise in the face of a decrease in fatigue level(18). This research is also in line with the research Wahyuni found that walking exercise program in breast cancer patients in IbnuSina Hospital reduced cancer-related fatigue with the results of the study with $p$-value $0.009(<0.05)$ which showed that there is an effect of walking exercise in reducing fatigue (10)

Doing physical exercise regularly and programmed, the immune system will increase. A good immune system will increase the number and function of Natural Killer cells which has a role as tumor suppression so that the risk of cancer decreases by recognizing and eliminating abnormal cells or through the innate or acquired immune system components. The dose of physical activity with immune function is inversely proportional, meaning that the dose is increasing the immune system while high doses suppress the immune system(17), while the study by Irianti and Ardinata said that there was an effect of moderate physical activity on leukocytes in untrained people(19). 
According to Lucía, Earnest, and Pérez, physical exercise can maximize cardiac morphology including increased ventricular mass and volume and increased diastolic filling and emptying and then increasing stroke volume so that ultimately increases cardiac output. Physical exercise also increases blood volume, which is followed by an increase in red blood cells, thus concentrating on increasing hemoglobin concentration. Physical exercise is known as a foundation intervention to carry out metabolic control. Muscle motion is the body's main tissue responsible for insulin stimulation glucose uptake and fat oxidation(20). Physical exercise can increase glucose uptake up to 20-100 times in the muscle through an insulin-independent mechanism that increases metabolism(21). From these processes, namely increasing hemoglobin and cardiac output, increasing oxygen flow can help reduce fatigue(22).

The mechanism of working physical exercise in dealing with fatigue in cancer clients will activate parasympathetic nerves which are then passed to the hypothalamus. Furthermore, the hypothalamus will reduce the stimulation of neurons to release the hormone $\mathrm{CRH}$ (Corticotropin-Releasing Hormone) to the anterior pituitary, so that the anterior pituitary inhibits the release of the hormone ACTH (Adrenocorticotropic Hormone) into the circulation. Barriers to ACTH release will inhibit the stimulation of the adrenal cortex to secrete glucocorticoids (cortisol) and the adrenal modula which produce catecholamine hormones, especially epinephrine and norepinephrine(21).

\section{CONCLUSION AND RECOMMENDATION}

In conclusion, there was a significant effect of physical exercise in reducing fatigue levels in patients with cervical cancer. It is recommended for nurses to train the patients so that increasing quality of life patients with cervical cancer. The Research Ethics Committee from the Commission of Health Research Ethics Faculty of Nursing University of Sumatera Utara No. 1154/XII/SP/ 2017.

\section{REFERENCES}

1. Katz AJ, Santoro M, Ashley R, Diblasio F, Shore N, Island L, et al. Stereotactic body radiation therapy for low- and lowintermediate-risk prostate cancer/ : is there a dose effect/ ? MATERIALS AND METHODS. 2011;1(December):1-6.

2. Pereira J, Green E, Molloy S, Dudgeon D, Howell D, Krzyzanowska MK, et al. Population-Based Standardized Symptom Screening/ : Cancer Care Ontario's Edmonton Symptom Assessment System and Performance Status Initiatives. J Oncol Pract. 2014;10(3):212-4.

3. Kemenkes RI. Panduan Program Nasional Gerakan Pencegahan Dan Deteksi Dini Kanker Leher Rahim Dan Kanker Payudara. 2015;(April):1-47.

4. Meneses-Echávez JF, González-Jiménez E, Ramírez-Vélez R. Effects of supervised exercise on cancer-related fatigue in breast cancer survivors: A systematic review and meta-analysis. BMC Cancer. 2015;15(1):113.

5. Liu L, Rissling M, Neikrug A, Fiorentino L, Natarajan L, Faierman M, et al. Fatigue and circadian activity rhythms in breast cancer patients before and after chemotherapy: a controlled study. Fatigue Biomed Heal Behav [Internet]. 2013;1(1-2):12-26. Available from: http://www.tandfonline.com/doi/abs/10.1080/ 21641846.2012.741782

6. Barsevick AM, Cleeland CS, Manning DC, O'Mara AM, Reeve BB, Scott JA, et al. ASCPRO Recommendations for the Assessment of Fatigue as an Outcome in Clinical Trials. J Pain Symptom Manage. 2010;39(6):1086-99.

7. Wang XS, Zhao F, Fisch MJ, O'Mara AM, Cella D, Mendoza TR, et al. Prevalence and characteristics of moderate to severe fatigue: A multicenter study in cancer patients and survivors. Cancer. 2014;120(3):425-32.

8. Atkinson TM, Li Y, Coffey CW, Sit L, Shaw M, Lavene D, et al. Reliability of adverse symptom event reporting by clinicians. Qual Life Res. 2012;21(7):1159-64.

9. Bower JE, Greendale G, Crosswell AD, Garet D, Sternlieb B, Ganz PA, et al. Yoga reduces inflammatory signaling in fatigued breast cancer survivors: A randomized controlled 
trial. Psychoneuroendocrinology [Internet]. $2014 ; 43: 20-9$. Available from: http:// dx.doi.org/10.1016/j.psyneuen.2014.01.019

10. Wahyuni SI, Sudiana KI, Mariyanti H. Walking Exercise Programme ( WEP ) Menurunkan Cancer Related Fatigue ( CRF ) Pada Pasien Kanker Payudara Di RSUD . Ibnu Sina Gresik. 2012;(1):2012.

11. Vitkauskaitë E, Juozaitytë E, DruktenienëJ, Bunevièius R. A systematic review of cancer related fatigue. J Oncol Inst. 2011;(2):74-7.

12. Cahyani P, Merdawati L, Fajria L. PENURUNAN SKOR FATIGUE PADA PASIEN KANKER DI RUMAH SAKIT KOTA PADANG TAHUN 2017 Penelitian Keperawatan Medikal Bedah. 2017;2-4.

13. Taukhid M. Manajemen Fatigue melalui Kombinasi Aerobik dengan Relaksasi Yoga pada Penderita Kanker Payudara dalam Program Kemoterapi. J Ilmu Kesehat. 2017;5(2):29-37.

14. Young-McCaughan S, Arzola SM. Exercise Intervention Research for Patients With Cancer on Treatment. Semin Oncol Nurs. 2007;23(4):264-74.

15. Labourey JL. Physical activity in the management of cancer-relatedfatigue induced by oncological treatments. Ann Readapt Med Phys. 2007;50(6):450-4.

16. Sulistini $R$, Yetti K. Faktor faktor yang mempengaruhi. 2008;

17. Mollaoglu M. Fatigue in people undergoing hemodialysis. Dial Transplant. 2009;38(6):216-20.

18. Dieli- CM. Exercise after breast cancer treatment/ : current perspectives. 2015;35362.

19. Ardinata D. Pengaruh Aktivitas Fisik Sedang terhadap Hitung Lekosit dan Hitung Jenis Lekosit pada Orang Tidak Terlatih. 2014;(June).

20. Lucía A, Earnest C, Pérez M. Cancer-related fatigue: Can exercise physiology assist oncologists? Lancet Oncol. 2003;4(10):61625.

21. Greenberg J. Psychoanalytic goals, therapeutic action, and the analyst's tension. Psychoanal Q [Internet]. 2002;71(4):651-78. Available from: http://www.ncbi.nlm.nih.gov/ pubmed/12391935
22. Jones LW, Eves ND, Haykowsky M, Freedland SJ, Mackey JR. Exercise intolerance in cancer and the role of exercise therapy to reverse dysfunction. Lancet Oncol [Internet]. 2009;10(6):598-605. Available from: http://dx.doi.org/10.1016/S14702045(09)70031-2 